\title{
Artificial Intelligence Simulating Grain Productivity During the Wheat Development Considering Biological And Environmental Indicators
}

Ângela Teresinha Woschinski De Mamann (Corresponding author)

Federal Institute of Education, Science and Technology of Rio Grande do Sul, Street

Nelsi Ribas Fritsch, 1111, Neighborhood Esperança, Ibirubá/RS - Brazil

Tel: +55 (55) 99999-5794Ｅ-mail: angela.mamann@ibiruba.ifrs.edu.br

José Antonio Gonzalez da Silva

Agrarian Studies Department, Regional University of the Northwest of Rio Grande do Sul, Street of Comércio 3000, Universitário, Ijuí/RS - Brazil

E-mail: jagsfaem@yahoo.com.br

Manuel Osório Binelo

Exact Sciences and Engineering Department, Regional University of the Northwest of Rio Grande do Sul, Street of Comércio 3000, Universitário, Ijuí/RS - Brazil

E-mail: manuel.binelo@unijui.edu.br

Osmar Bruneslau Scremin

Exact Sciences and Engineering Department, Regional University of the Northwest of Rio Grande do Sul, Street of Comércio 3000, Universitário, Ijuí/RS - Brazil

E-mail: osmarscremin@ @otmail.com

Adriana Roselia Kraisig

Exact Sciences and Engineering Department, Regional University of the Northwest of Rio Grande do Sul, Street of Comércio 3000, Universitário, Ijuí/RS - Brazil

E-mail: maryshelei@yahoo.com.br

Ivan Ricardo Carvalho

Agrarian Studies Department, Regional University of the Northwest of Rio Grande do Sul, Street of Comércio 3000, Universitário, Ijuí/RS - Brazil

E-mail: carvalho.irc@gmail.com

Laura Mensch Pereira

Agrarian Studies Department, Regional University of the Northwest of Rio Grande do Sul, 
Street of Comércio 3000, Universitário, Ijuí/RS - Brazil

E-mail: lauramensch@gmail.com

Julio Daronco Berlezi

Agrarian Studies Department, Regional University of the Northwest of Rio Grande do Sul, Street of Comércio 3000, Universitário, Ijuí/RS - Brazil

E-mail: julio.berlezi28@hotmail.com

Cláudia Vanessa Argenta

Agrarian Studies Department, Regional University of the Northwest of Rio Grande do Sul, Street of Comércio 3000, Universitário, Ijuí/RS - Brazil

E-mail: claudia_argenta@yahoo.com

Received: July 28, 2019

doi:10.5296/jas.v7i3.15153
Accepted: August 15, 2019

Published: August 19, 2019

URL: https://doi.org/10.5296/jas.v7i3.15153

\begin{abstract}
The artificial neural networks modeling might simulate the efficiency of wheat grain yield involving biological and environmental conditions during the development cycle. Considering the main succession systems in wheat crop in Brazil, the study aimed to adapt an artificial neural network architecture capable of predict the wheat grain productivity throughout the growth cycle, involving nitrogen and non-linearity of maximum air temperature and rainfall. The field experiment was conducted in two successions systems (soybean/wheat and maize/wheat) in 2017 and 2018, the trial design was in a randomize blocs with eight replicate in the level $0,30,60$, and $120 \mathrm{~kg} \mathrm{ha}^{-1} \mathrm{~N}$-fertilizer doses in the phenological stage of third fully expanded leaves. Every 30 day of the development cycle were obtained the biomass yield, maximum air temperature and accumulated rainfall information. The perceptron multi-layered artificial neural networks with backpropagation algorithm with network architecture 5-8-1 and 5-7-1 in soybean/wheat and maize/wheat system respectively, is able to simulate the wheat grain yield involving the nitrogen dose at top-dressing and the non-linearity of maximum air temperature and rainfall with biomass information obtained during the cycle crop.
\end{abstract}

Keywords: Triticum aestivum, artificial neural networks, maximum air temperature, rainfall, sustainability

\title{
1. Introduction
}

The artificial neural networks (ANN) are computing algorithm that shows a mathematical model inspired by the intelligent organisms whom enable the neural networks humans in the 
computers systems (Çelebi et al., 2017; Dornelles et al., 2018). These networks are artificial neurons that can be dispense into several layers and interconnected by connections that store model knowledge and consider the input per each neurons in the network (Vendruscolo et al., 2015; Menezes et al., 2015). Therefore, ANN learn by the experience, generalize information and estimate results to not known data (Wasserman, 1989; Silva et al., 2018). Enhancing the optimization processes to make decisions in agriculture. The ANN can be used to elaborate prediction models in complex systems and estimate desired parameters (Huang et al., 2010; Silva et al., 2014).

There is a need to optimize food production through technologies that ensure yields with lower costs and sustainable to the agroecosystems (Sala et al., 2005; Viola et al., 2013). Once, wheat is the most cultivated and consumed cereal all over the world with great importance in human feed (Santos and Medeiros, 2016; Frizon et al., 2017), which requires researches to intensify its production with sustainability. For greater yield in wheat, the nitrogen is an essential element (Teixeira Filho et al., 2010; Prando et al., 2013), however, its management is one of most complex due to the high losses index by leaching and volatilization, increasing the production expenses and generating environmental pollution (Silva et al., 2015; Camponogara et al., 2016). Furthermore, meteorological elements such as rainfall and air temperature are close related to nitrogen uses or losses by the plant, and related to the wheat productivity expression (Bischoff et al., 2015; Santi et al., 2017). Those elements are non-linear variable that become difficult its use in the math modeling to predict the productivity. The usage of computational algorithms via ANN can represent a promising tool to aggregate information of biological and environmental variable, with linear or non-linear behavior, allowing it to recognise patterns in the prognosis generation.

The study aimed to adapt an ANN capable of predict the wheat grain productivity throughout the growth cycle, involving nitrogen and non-linearity of maximum air temperature and rainfall, considering the main succession systems in wheat crop in Brazil.

\section{Materials and Methods}

\subsection{Crop Area Description}

The experiment was developed on field in the 2017 and 2018 agricultural years, located in Augusto Pestana, RS, Brazil (28 $26^{\circ}$ '30' S; $54^{\circ} 00^{\prime} 58^{\prime \prime} \mathrm{W}$ ). The growing soil is classified as Oxisol Distroferric Typical and the climate of the region matches to CFA (humid subtropical), with the occurrence of hot summers, no occurrence of prolonged droughts, and cold wet winters, according to Köppen's classification. The soil analysis was realized ten days before sowing and had the following features chemistry (Tedesco et al., 1995): i) maize/wheat system: $\left(\mathrm{pH}=6,5 ; \mathrm{P}=34,4 \mathrm{mg} \mathrm{dm}^{-3} ; \mathrm{K}=262 \mathrm{mg} \mathrm{dm}^{-3} ; \mathrm{MO}=2,9 \% ; \mathrm{Al}=0 \mathrm{cmolcdm}^{-3} ; \mathrm{Ca}=\right.$ $\left.6,6 \mathrm{cmolcdm}^{-3} \mathrm{e} \mathrm{Mg}=3,4 \mathrm{cmolcdm}^{-3}\right)$ and; ii) soybean/oat system: $(\mathrm{pH}=6,2 ; \mathrm{P}=33,9 \mathrm{mg}$ $\mathrm{dm}^{-3} ; \mathrm{K}=200 \mathrm{mg} \mathrm{dm}^{-3} ; \mathrm{MO}=3,0 \% ; \mathrm{Al}=0 \mathrm{cmolcdm}^{-3} ; \mathrm{Ca}=6,5 \mathrm{cmolcdm}^{-3} \mathrm{e} \mathrm{Mg}=2,5$ $\mathrm{cmolcdm}^{-3}$ ). Regardless the agricultural year, the sowing performed on June third week according to the crop recommendation on residual cover with higher and lower $\mathrm{C} / \mathrm{N}$ relation, maize/wheat system and soybean/oat system respectively. 


\subsection{Experimental Design}

The seed were sown with a seeder-fertilizer in five 5-m-length lines spaced by $0.20 \mathrm{~m}$. The population density was 400 seeds $\mathrm{m}^{-2}$ viable seeds. During the study accomplishment was applied tebuconazole fungicide at a dose of $0.75 \mathrm{~L} \mathrm{ha}^{-1}$. The weeds were controlled by metsulfuron-methyl herbicide at a dose of $4 \mathrm{~g} \mathrm{ha}^{-1}$ and hoed when necessary. At the sowing was applied 45 e $30 \mathrm{~kg} \mathrm{ha}^{-1}$ of $\mathrm{P}_{2} \mathrm{O}_{5}$ e $\mathrm{K}_{2} \mathrm{O}$ based on $\mathrm{P}$ and $\mathrm{K}$ soil contents to $3000 \mathrm{~kg} \mathrm{ha}^{-1}$ grain yield expected respectively and $10 \mathrm{~kg} \mathrm{ha}^{-1}$ of $\mathrm{N}$-starter-fertilizer (except the pattern experimental unity) with the residual to complete the proposal top-dressing $\mathrm{N}$ dose in the phenological stage of third fully expanded leaves.

Two experimental studies was performed in each crop condition (soybean/wheat, maize/wheat systems). One to quantify biomass yield through the cutting performed every 30 days until physiological maturity and the other to grain yield estimative. Therefore, at the four experiment the trial design was in a randomize blocs with eight replicate for four $\mathrm{N}$-fertilizer doses (urea) in the level $0,30,60$, and $120 \mathrm{~kg} \mathrm{ha}^{-1}$ with the TEC 10 wheat cultivar, total of 128 experimental units. The grain yield was obtained by cutting the three central line of each plot at the harvest maturity, then was threshed and the grain moisture corrected to $13 \%$ at the laboratory to the grain yield estimative $\left(\mathrm{GY}, \mathrm{kg} \mathrm{ha}^{-1}\right)$. To quantify biomass yield (BY, kg ha ${ }^{-1}$ ) the material plant was harvest close to the soil by collecting a linear meter in the three central lines of each plot in 30,60, 90, and 120 days after emergence, total of four cutting.

To estimate biomass yield the plant material were dried in a forced-air oven at $65{ }^{\circ} \mathrm{C}$ until stabilized weight. The meteorological data of maximum and minimum air temperature and rainfall amount over the wheat growth cycle were obtained through Total Automatic Station installed 500 meters from the experiment.

\subsection{Modeling for Artificial Neural Networks}

The artificial neural networks (ANN) proposed consist in perceptron multi-layered (PML) by Rosenblatt (1958). These networks are trained using backprogamation algorithm set with optimize algorithm Levemberg-Merquadt (LM), with the ability to treat data no linearly separable, with one input layer, hidden layer (at least) and one output layer (Gonçalves et al., 2010; Perea et al., 2018). The input layer is responsible to receive information, signal, features or mediations that come from the outside. Generally are normalized in relation to the dynamic variation range produced by the activation functions (Silva et al., 2010). The hidden layer is composed of neurons with the responsibility to extract related features to the process or the system to infer. On this layer the processing performed per each neuron is defined by the combination of the process realized by the neurons from the previous layers connected to it (Meireles and Cedón, 2010). The output layer generate the production and shows the final network results, that accrue from the neurons processing performed from the previous layers. (Silva et al., 2010). The backpropagation algorithm is based on the precept of learning through the error correction, that is, in forward process the input vector spreads out ANN layers producing an output layer with stabilized weight. In the reverse process, the weight are readjusted as follow the learning rule by error correction. (Fleck et al., 2016). The optimize 


\section{Macrothink Institute ${ }^{T M}$}

algorithm Levenberg-Merquad require less training period and is automatic interrupt when the generalization minimizes the difference between real and simulated network. It was used the activation function hyperbolic tangent sigmoid.

\subsection{ANN Applicability by Environmental and Biological Indicators}

The input variables usage by the ANN were: $\mathrm{N}$-fertilizer dose $\left(0,30,60\right.$ e $\left.120 \mathrm{~kg} \mathrm{ha}^{-1}\right)$, growth stages (30, 60, 90 e 120 days), biomass yield (in each growth stages), rainfall and maximum mean air temperature at each stage. The output variable was grain yield, whereas the main cereal succession systems in Brazil (Figure 1).

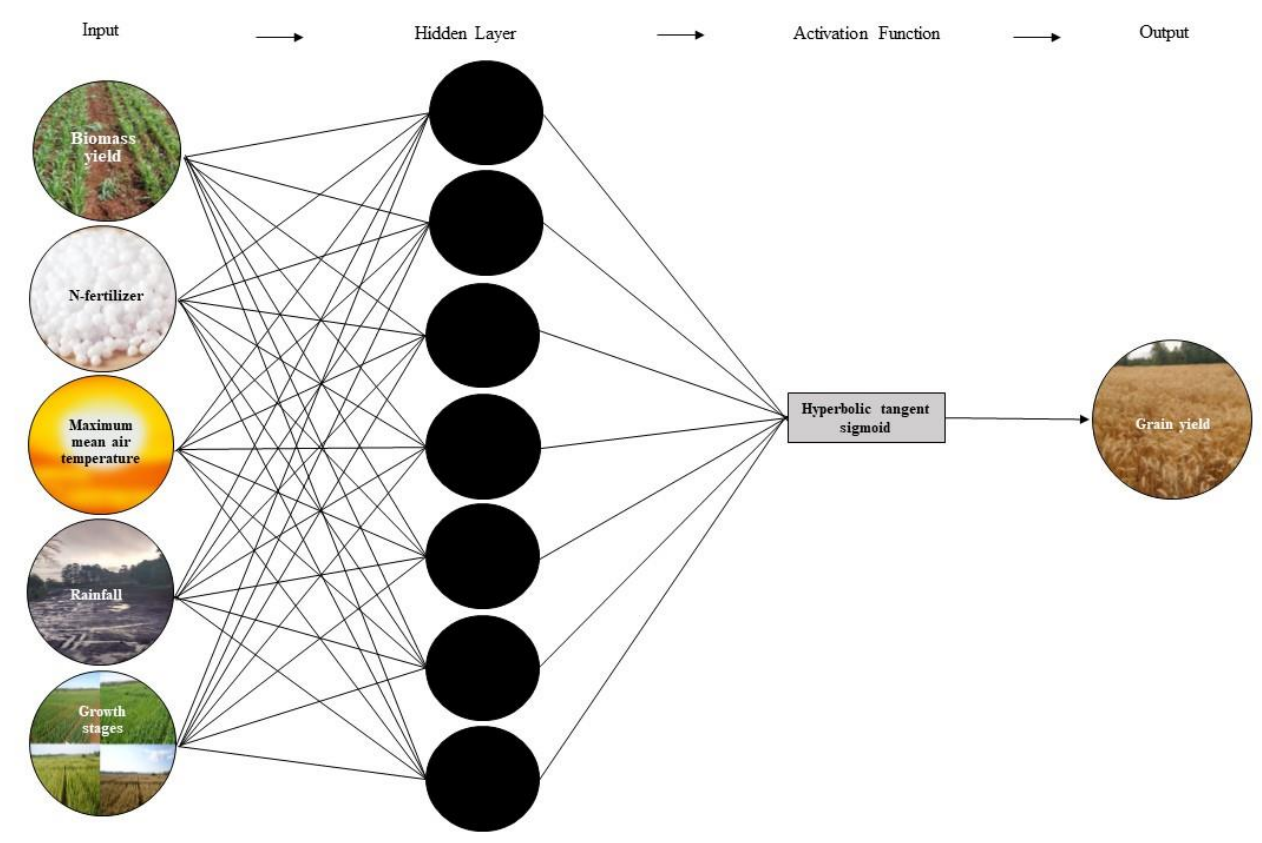

Figure 1. Artificial neural networks by biological and environmental indicators in grain yield simulation of wheat

The training process was begun with weight random values of the variable and this data the output was compared with the real value. The difference between the output network and the real value generate an error signal who adjust the weight and starts a new cycle, to bring the output closer the desired result minimized the error (Vendruscolo et al, 2015). It was training 10 ANN with 3 layers (input, hidden and output) The input layer consisted in 5 neurons, the hidden layer had 5 to 10 neurons with increment 1 on 1 and the output layer with 1 neuron. After training each ANN architecture, were choose the lowest mean relative error (MRE) regard the validation data, and the lowest mean squared error (MSE) related to the training data. To represent the ANN architecture were used the signal "NI-NHL-NNO" being NI = input variable numbers, NHL = hidden layer neuron numbers and NNO = output layer neuron numbers. For the ANN architecture, the data (dataset with 128 samples) were random divided in $70 \%$ to the training, $15 \%$ to test and $15 \%$ to validation. To the multilayer ANN training and simulation of wheat grain productivity was used the Neural Network Toolbox MATLAB® software. 


\section{Macrothink}

To ANN validation chosen in each crop system was consider the behavior and parameters of the polynomial regression obtained from the variable real value on the different nitrogen doses by the bio-experimentation. The quadratic equation (Equation 1) used to estimate the maximum technical efficiency (Equation 2) of nitrogen use, considering the model:

$$
G Y=b_{0} \pm b_{1} x \pm b_{2} x^{2}
$$

being, $G Y=$ grain yield $\left(\mathrm{kg} \mathrm{ha}^{-1}\right) b_{0}, b_{1}$ e $b_{2}$ are the regression model parameters

$$
M T E=-\frac{b_{1}}{2 b_{2}}
$$

being, MTE nitrogen maximum technical efficiency $\left(\mathrm{kg} \mathrm{ha}^{-1}\right)$.

In the regression models, determination was use the Excel computing program.

\section{Results and Discussion}

In the Figure 2 of the wheat crop cycle was observed that the rainfall in 2017 (Figure 2A) and 2018 (Figure 2B) were similar to the historical average last 20 years of $900 \mathrm{~mm}$, however, with different distribution between the years (Figure 2). In 2017, occurred lower rainfall intensity at the cycle beginning with great maximum air temperature, this condition favors the $\mathrm{N}$-fertilizer loses through volatilization. On the other hand, the greater rainfall amount was from half wheat cycle to maturation in 2017 (Figure 2A), this favored minor sunstroke periods that indicated fewer photosynthesis efficiency harming the grain productivity.
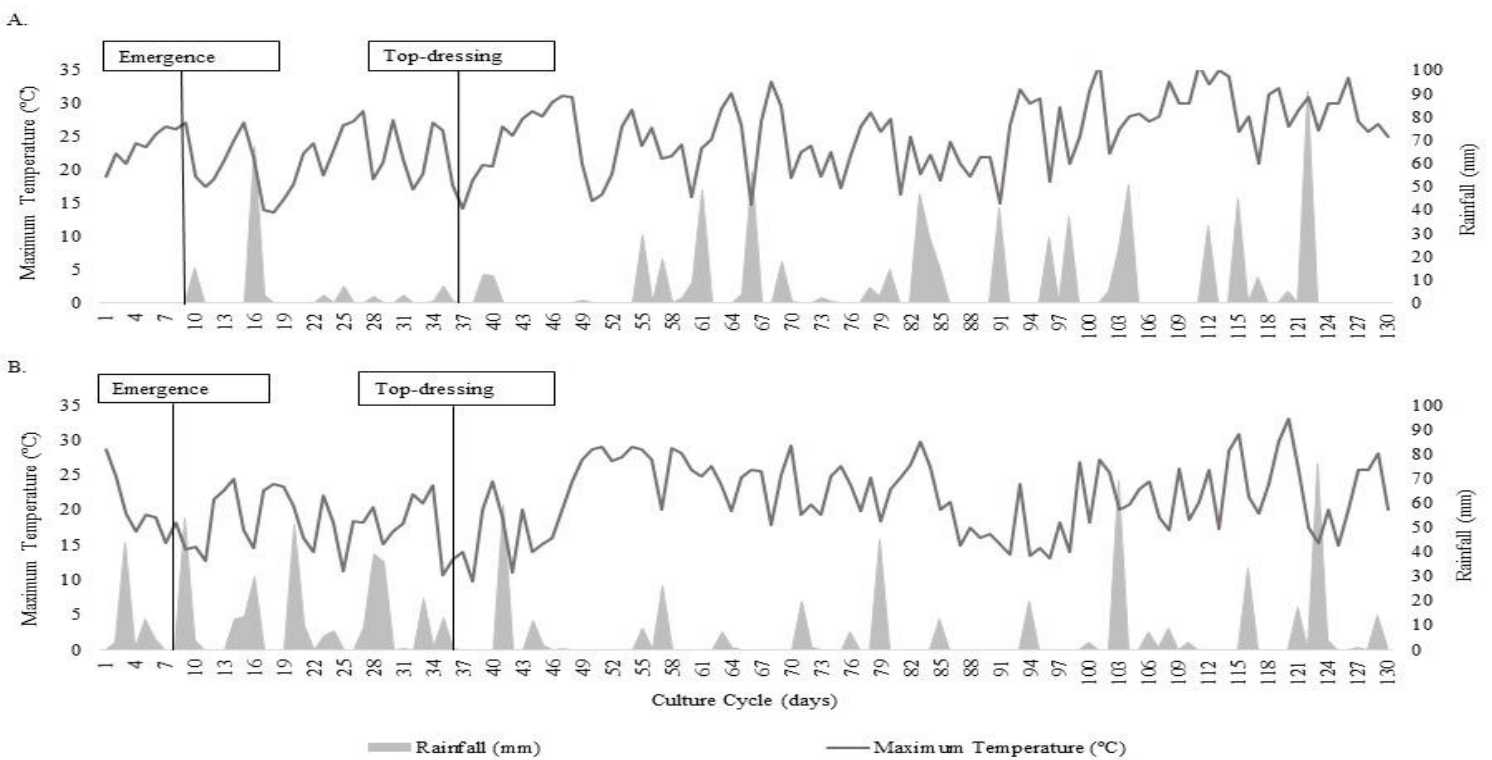

Figure 2. Rainfall and maximum temperature in wheat development. (A) agricultural year 2017 with $1576 \mathrm{~kg} \mathrm{ha}^{-1}$ grain yield; (B) Agricultural year 2018 with $2246 \mathrm{~kg} \mathrm{ha}^{-1}$ 


\section{Macrothink}

Journal of Agricultural Studies

ISSN 2166-0379

2019, Vol. 7, No. 3

In 2018 (Figure 2B) the greater rainfall was from sowing to 40 days of wheat development and with maximum air temperature lower them registered in 2017. The rainfall had lower intensity and better distribution from the reproductive growth stages to maturity (Figure 2B), facts that gives out the greater grain yield in 2018 in relation to 2017.

Although the technological and scientific advances, the climate still is the most important variable on agriculture (Ayoade, 2010). Being one of the major factors responsible for the cropping variation (Lucena et al., 2012). The climate interfere under many agriculture steps as: the ideal conditions of tillage, sowing period, harvest, carriage, storage and others (Cunha, 2013). On it, rainfall and air temperature are the meteorological variable crucial for the yield farming success (Baldisera and Dallacort, 2017). The water shortfall induce the plants stomatal closure leading to reduction transpiration and photosynthesis (Souza et al., 2019), committing the productivity and hence the economy and food security (Pohlmann and Lazzari, 2018). Therefore, the rainfall is the decisive variable to comprehend agricultural strategy (Junges et al., 2019). Besides, higher temperatures promote biomass yield reduction by the raise respiration rate and stomatal closure, reducing photosynthesis and favours nitrogen losses by volatilization during fertilization (Costa et al., 2018). For instance, as temperature is related to atmospheric humidity, solar radiation, wind speed, rainfall, evaporation and transpiration, can provide valuable information for the crop planning (Ahmadi et al., 2018).

In Table 1, regardless the crop system and N-fertilizer dose, in 2017 showed values of biomass productivity upper 2018, until the 60 days after emergence. Although the maximum temperature average had been lower in 2018, which should further the crop, the lowest productivity can be explain due to the rainfall amount, provided large periods without sunlight, limiting the photosynthesis efficiency to biomass yield (Table 1). Stem from the 90 days after emergence, the biomass yield range between the years 2017 and 2018 significantly decreased (Table 1) indicate similarity. In addition, in 120 days after emergence shows a reversal in maize/wheat system, with biomass yield in 2018 upper then 2017. 
Table 1. Meteorological data and biomass yield in wheat phenological stages with nitrogen use

\begin{tabular}{|c|c|c|c|c|c|}
\hline $\begin{array}{l}\text { Phenological } \\
\text { stages (days) }\end{array}$ & Year & $\sum$ Rain & $\bar{X}_{\operatorname{MaxT}}$ & $\begin{array}{l}\text { soybean/maize } \\
\text { BY }\left(\mathrm{kg} \mathrm{ha}^{-1}\right)\end{array}$ & $\frac{\text { maize/wheat }}{\mathrm{BY}\left(\mathrm{kg} \mathrm{ha}^{-1}\right)}$ \\
\hline \multicolumn{6}{|c|}{$0 \mathrm{~kg} \mathrm{ha}^{-1}$ of $\mathrm{N}$} \\
\hline \multirow{2}{*}{30} & 2017 & 112 & 21.3 & 368 & 236 \\
\hline & 2018 & 308 & 18.1 & 170 & 130 \\
\hline \multirow{2}{*}{60} & 2017 & 307 & 23.0 & 1962 & 858 \\
\hline & 2018 & 437 & 20.3 & 1090 & 557 \\
\hline \multirow{2}{*}{90} & 2017 & 548 & 23.1 & 6546 & 3685 \\
\hline & 2018 & 570 & 20.4 & 5532 & 2855 \\
\hline \multirow{2}{*}{120} & 2017 & 813 & 24.7 & 6765 & 4651 \\
\hline & 2018 & 736 & 21.0 & 6340 & 5402 \\
\hline \multicolumn{6}{|c|}{$30 \mathrm{~kg} \mathrm{ha}^{-1}$ of $\mathrm{N}$} \\
\hline \multirow{2}{*}{30} & 2017 & 112 & 21.3 & 335 & 242 \\
\hline & 2018 & 308 & 18,1 & 202 & 111 \\
\hline \multirow{2}{*}{60} & 2017 & 307 & 23.0 & 2880 & 1036 \\
\hline & 2018 & 437 & 20.3 & 1654 & 665 \\
\hline \multirow{2}{*}{90} & 2017 & 548 & 23.1 & 7785 & 4979 \\
\hline & 2018 & 570 & 20.4 & 7838 & 4019 \\
\hline \multirow{2}{*}{120} & 2017 & 813 & 24.7 & 7818 & 5666 \\
\hline & 2018 & 736 & 21.0 & 8071 & 7535 \\
\hline \multicolumn{6}{|c|}{$60 \mathrm{~kg} \mathrm{ha}^{-1}$ of $\mathrm{N}$} \\
\hline \multirow{2}{*}{30} & 2017 & 112 & 21.3 & 328 & 221 \\
\hline & 2018 & 308 & 18.1 & 188 & 116 \\
\hline \multirow{2}{*}{60} & 2017 & 307 & 23.0 & 3043 & 1854 \\
\hline & 2018 & 437 & 20.3 & 1813 & 1234 \\
\hline \multirow{2}{*}{90} & 2017 & 548 & 23.1 & 7742 & 5809 \\
\hline & 2018 & 570 & 20.4 & 7445 & 6380 \\
\hline \multirow{2}{*}{120} & 2017 & 813 & 24.7 & 8474 & 5859 \\
\hline & 2018 & 736 & 21.0 & 8844 & 8685 \\
\hline \multicolumn{6}{|c|}{$120 \mathrm{~kg} \mathrm{ha}^{-1}$ of $\mathrm{N}$} \\
\hline \multirow{2}{*}{30} & 2017 & 112 & 21.3 & 359 & 244 \\
\hline & 2018 & 308 & 18.1 & 201 & 110 \\
\hline \multirow{2}{*}{60} & 2017 & 307 & 23.0 & 3630 & 1967 \\
\hline & 2018 & 437 & 20.3 & 1804 & 1521 \\
\hline \multirow{2}{*}{90} & 2017 & 548 & 23.1 & 8964 & 7321 \\
\hline & 2018 & 570 & 20.4 & 9117 & 7750 \\
\hline \multirow{2}{*}{120} & 2017 & 813 & 24.7 & 10860 & 7520 \\
\hline & 2018 & 736 & 21.0 & 10533 & 11033 \\
\hline
\end{tabular}

N - nitrogen; BY- biomass yield; $\sum$ Rain - rainfall sum (mm); $\bar{X}_{\text {MaxT }}$ - maximum temperature average $\left({ }^{\circ} \mathrm{C}\right)$

The results in Table 1 shown complexity action of meteorological condition over yield expression that is direct affect over the development cycle, what justify the need of models more efficient and computational techniques to move on reliable predictions. It is worth highlighting that this information (Table 1) engage the complexity of biological and environmental variables and linear and non-linear effects during the crop. It will be used on artificial neural networks (ANN) training in proposal the simulation of wheat grain yield during the development cycle. This perspective, in Table 2, are shown the mean squared error, 
mean relative error and variance, observed during the test and validation process for ANN architecture to distinct successions systems.

Table 2. Dimensionless values of the mean squared error to training data, mean relative error and variance to validation data on the training architecture

\begin{tabular}{cccc}
\hline $\begin{array}{c}\text { Architecture } \\
\text { NI-NHL-NNO }\end{array}$ & Mean squared error (training) & Mean relative error (validation) & Variance (validation) \\
\hline & Soybean/wheat system (2017+2018) & \\
$5-5-1$ & 0.0165 & 0.0312 & 0.0206 \\
$5-6-1$ & 0.0055 & 0.0776 & 0.0182 \\
$5-7-1$ & 0.0091 & 0.0241 & 0.0170 \\
$5-8-1$ & 0.0015 & 0.0150 & 0.0180 \\
$5-9-1$ & 0.0088 & 0.0244 & 0.0196 \\
$5-10-1$ & 0.0095 & 0.0250 & 0.0175 \\
$5-5-1$ & Maize/wheat system (2017+2018) \\
$5-6-1$ & 0.0063 & 0.0047 & 0.0777 \\
$5-7-1$ & 0.0071 & 0.0163 & 0.0256 \\
$5-8-1$ & 0.0078 & 0.0012 & 0.0276 \\
$5-9-1$ & 0.0075 & 0.0814 & 0.0300 \\
$5-10-1$ & 0.0079 & 0.0293 & 0.0159 \\
\hline
\end{tabular}

NI - input variable numbers, NHL - hidden layer neuron numbers and NNO - output layer neuron numbers

To simulated the ANN in wheat grain yield was choose, considering the architecture, whom presented differences between the amount of neurons on the hidden layer and the input layer equal or greater a two and between the lowest mean relative error on the validation and training process. Highlight that the chosen architecture were 5-8-1 to soybean/wheat system and 5-7-1 to maize/wheat system, values that represent the amount of neuron on input layer, hidden layer and output layer, respectively (Table 2). This way, the Figure 3 shows the determination coefficients $\left(\mathrm{R}^{2}\right)$ close to one on the training, test and validation process. It allows to confirm the ANN trust in generate algorithm who dimension the real data behavior and generalise the learning to simulation the wheat grain yield, considering the inclusion of biological and environmental variable on the computational process. 

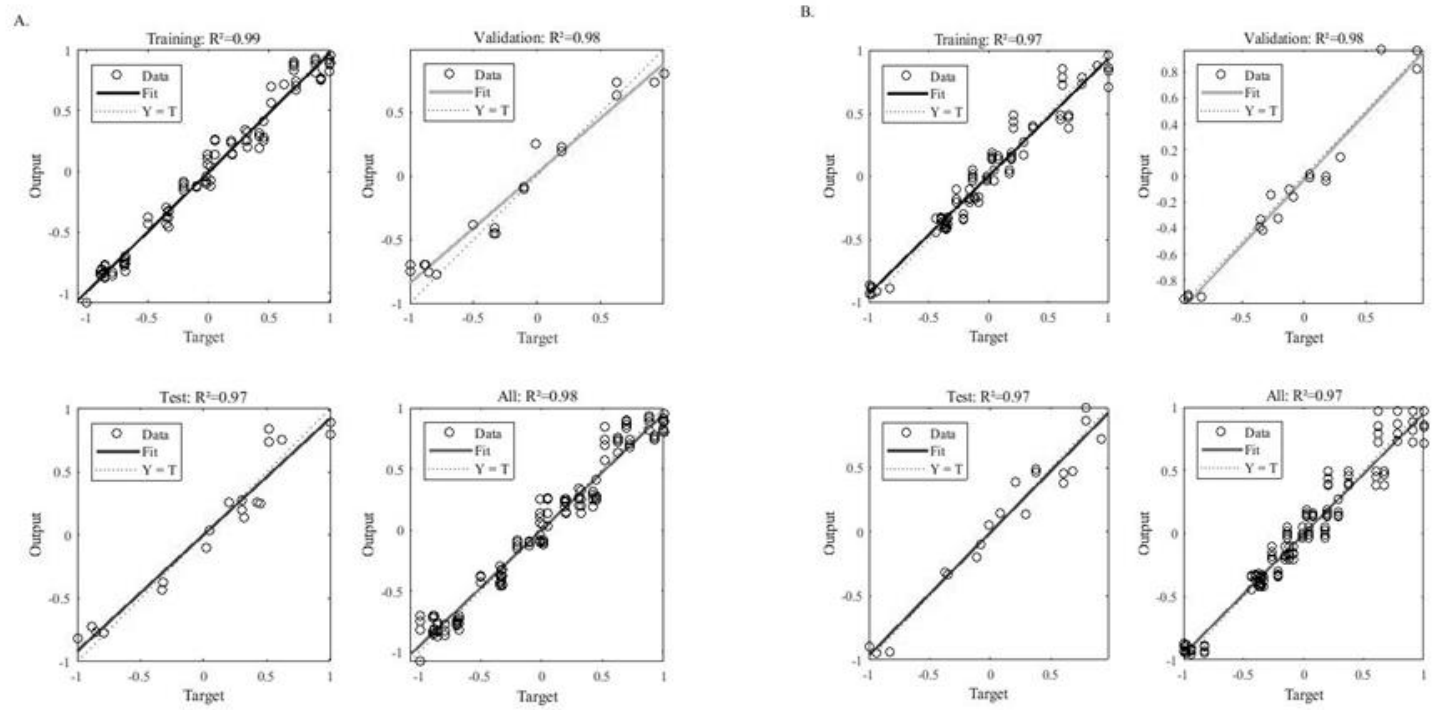

Figure 3. Determination coefficient of training, test, validation, and all neural artificial networks. (A) Architecture 5-8-1 to soybean/wheat system; (B) Architecture 5-7-1 to maize/wheat system

In Table 3, shown the average comparison of wheat grain yield observed and simulated through ANN for each crop system. Stands out, the grain yield increased due to the nitrogen dose rise, evidencing a quadratic behavior (Figure 4). This same pattern also was recognized by the ANN since the simulation on 30 days after the emergence, regardless the crop system. To illustrate, in soybean/wheat system highlight the nitrogen $120 \mathrm{~kg} \mathrm{ha}^{-1}$ condition with average $2728 \mathrm{~kg} \mathrm{ha}^{-1}$ wheat grain yield, and the ANN simulation shown on the 30 days after emergence the average $2801 \mathrm{~kg} \mathrm{ha}^{-1}$ grain yield. These results differs (AE) in just $73 \mathrm{~kg} \mathrm{ha}^{-1}$ grain, which confirm the high ability of ANN to prediction. Thus, stands out that the greater AE were under $200 \mathrm{~kg} \mathrm{ha}^{-1}$ wheat grain (Table 3), fact that vouch the ANN validation on predictability grain yield. 


\section{IIMacrothink}

Journal of Agricultural Studies

ISSN 2166-0379

2019, Vol. 7, No. 3

Table 3. ANN simulation in wheat grain yield in distinct phenological stages with nitrogen use

\begin{tabular}{|c|c|c|c|c|c|c|c|}
\hline \multirow{2}{*}{$\begin{array}{c}\mathrm{N} \\
\left(\mathrm{kg} \mathrm{ha}^{-1}\right)\end{array}$} & \multirow{2}{*}{$\begin{array}{l}\text { phenological } \\
\text { stage } \\
\text { (days) }\end{array}$} & \multicolumn{3}{|c|}{ Soybean/wheat system } & \multicolumn{3}{|c|}{ Maize/what system } \\
\hline & & GYs & $\overline{\bar{X}} G Y_{O}$ & $\mathrm{AE}$ & GYs & $\overline{\bar{X}} G Y_{O}$ & $\mathrm{AE}$ \\
\hline \multicolumn{8}{|c|}{$(2017+2018)$} \\
\hline \multirow{4}{*}{0} & 30 & 1421 & \multirow{4}{*}{1381} & 40 & 959 & \multirow{4}{*}{880} & 79 \\
\hline & 60 & 1391 & & 10 & 860 & & 20 \\
\hline & 90 & 1434 & & 53 & 957 & & 77 \\
\hline & 120 & 1372 & & 9 & 916 & & 36 \\
\hline \multirow{4}{*}{30} & 30 & 2358 & \multirow{4}{*}{2167} & 191 & 1439 & & 29 \\
\hline & 60 & 2245 & & 78 & 1450 & \multirow{3}{*}{1468} & 18 \\
\hline & 90 & 2263 & & 96 & 1450 & & 18 \\
\hline & 120 & 2283 & & 116 & 1381 & & 87 \\
\hline \multirow{4}{*}{60} & 30 & 2724 & \multirow{4}{*}{2542} & 182 & 1740 & \multirow{4}{*}{1716} & 24 \\
\hline & 60 & 2559 & & 17 & 1765 & & 49 \\
\hline & 90 & 2550 & & 8 & 1791 & & 75 \\
\hline & 120 & 2604 & & 62 & 1626 & & 90 \\
\hline \multirow{4}{*}{120} & 30 & 2801 & \multirow{4}{*}{2728} & 73 & 2126 & \multirow{4}{*}{1948} & 178 \\
\hline & 60 & 2766 & & 38 & 2102 & & 154 \\
\hline & 90 & 2780 & & 52 & 1890 & & 58 \\
\hline & 120 & 2843 & & 115 & 1769 & & 179 \\
\hline
\end{tabular}

$\mathrm{N}$ - nitrogen; GYs - simulated grain yield $\left(\mathrm{kg} \mathrm{ha}^{-1}\right) ; \bar{X} G Y o$ - observed grain yield average (kg $\left.\mathrm{ha}^{-1}\right) ; \mathrm{AE}$ - absolute error $\left(\mathrm{kg} \mathrm{ha}^{-1}\right)$

The Figure 4, regardless the crop system, evidence the quadratic behavior for wheat grain yield on crop field and simulated in ANN. For quadratic behavior in soybean/wheat system (Figure 4A), the maximum technical efficiency of nitrogen use by the real data was with 100 $\mathrm{kg} \mathrm{ha}^{-1}$. The quadratic equation obtain through ANN simulation shown maximum technical efficiency in $93 \mathrm{~kg} \mathrm{ha}^{-1}$ nitrogen, a slight variation of $7 \mathrm{~kg} \mathrm{ha}^{-1}$ that would not modify the productivity on real cropping.
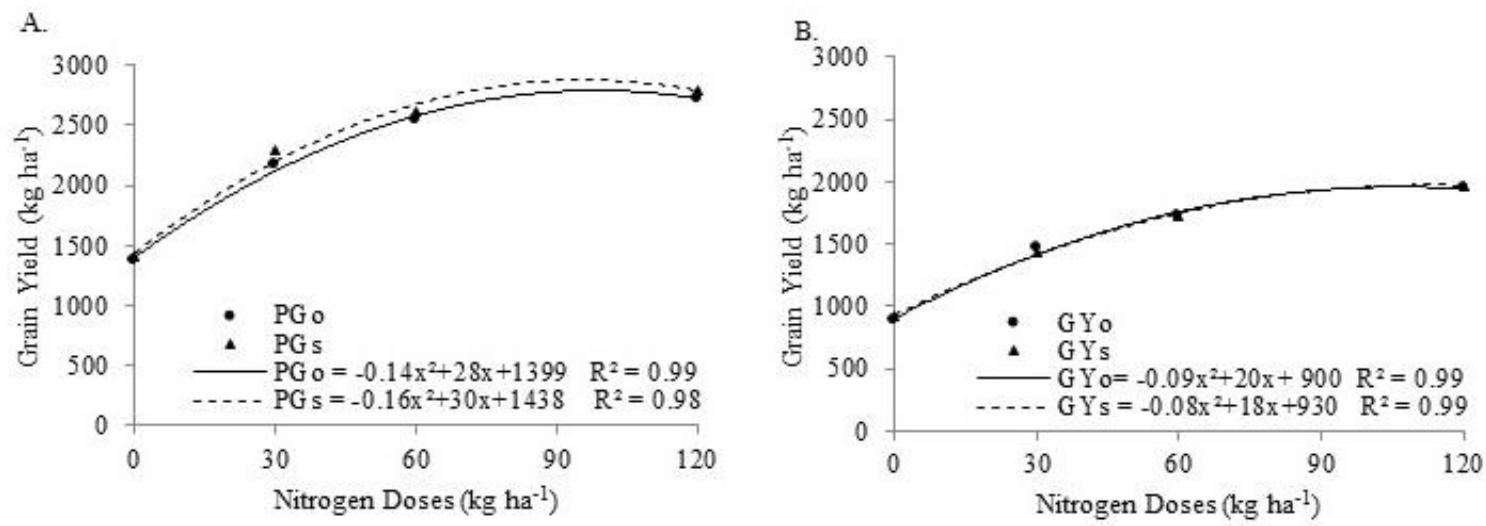

Figure 4. Behavior and parameters of grain yield regression equation observed and simulated by artificial neural network. GYo - grain yield observed $\left(\mathrm{kg} \mathrm{ha}^{-1}\right)$; GYs - grain yield simulated $\left(\mathrm{kg} \mathrm{ha}^{-1}\right) ; \mathrm{R}^{2}$ - determination coefficient; (A) soybean/wheat system; (B) maize/wheat system 
In maize/wheat system (Figure 4B), the maximum technical efficiency of nitrogen use with real crop field data was $111 \mathrm{~kg} \mathrm{ha}^{-1}$. The equation created with simulated values by ANN shown maximum technical efficiency $113 \mathrm{~kg} \mathrm{ha}^{-1}$ nitrogen. Also on this condition, the slight variation observed was $2 \mathrm{~kg} \mathrm{ha}^{-1}$ who ensure the technique quality in proposition to ally biological and environmental indices to simulate wheat grain yield over the development cycle. Therefore, is possible to validate the ANN use on grain yield predictability in each wheat phenological stage, in different condition of nitrogen use on distinct succession systems, regard to the non-linearity of maximum air temperature and rainfall with biomass information obtained during the crop cycle.

The ANN allows complex systems modeling who has properties as: function capacity, linear and non-linear multiple variables with unknown interactions and good generalization capacity (Demuth et al., 2014). These models are able to quickly process a large data amount and recognise patterns based on self-learning (Teodoro et al., 2015). Therefore, the ANN has been awakening the agricultural interest due to the simulation ability and process optimization. On this perspective, detaches the studies conducted with the optimization of oats seeding rate with grain yield forecast (Dornelles et al., 2018), eucalypt volume simulation considering biological different parameters of the specie (Bhering et al., 2015), tree height simulation with different growth conditions (Campos et al., 2016). Soybean yield simulation with agronomic features, growth habits and population density (Alves et al., 2018). In maize, Soares et al. (2015) had used morphological variable to simulate the crop grain yield using multilayer ANN with backpropagation training algorithm. Reis et al. (2018) also used this ANN model to project a diametrical distribution in Amazônia.

\section{Conclusion}

The multilayer artificial neural networks with the backpropagation learning algorithm and with the network architecture 5-8-1 and 5-7-1 on soybean/wheat and maize/wheat, respectively, is able to simulate wheat grain yield with the nitrogen dose at top-dressing and non-linearity of the maximum air temperature and rainfall with biomass information obtained during the crop cycle.

\section{Acknowledgement}

To the Coordination for the Improvement of Higher Education Personnel, National Council for Scientific and Technological Development, Rio Grande do Sul Research Support Foundation and the Regional University of the Northwest of Rio Grande do Sul, to Federal Institute of Education, Science and Technology of Rio Grande do Sul for the financial support to the research and for the Scientific and Technological Initiation Scholarship, Postgraduate Scholarship and Research Productivity Grant.

\section{References}

Ahmadi, F., Tahroudi, M. N., Mirabbasi, R., Khalili, K., \& Jhajharia, D. (2018). Spatiotemporal trend and abrupt change analysis of temperature in Iran. Meteorological Applications, 25(2), 314-321. https://doi.org/10.1002/met.1694 
Alves, G. R., Teixeira, I. R., Melo, F. R., Souza, R. T. G., \& Silva, A. G. (2018). Estimating soybean yields with artificial neural networks. Acta Scientiarum - Agronomy, 40(1), 1-9. https://doi.org/10.4025/actasciagron.v40i1.35250

Ayoade, J. O. (2010). Introduction to climatology for the tropics. (6rd ed.) Rio de Janeiro: Bertrand Brazil.

Baldisera, R. S., \& Dallacort, R. (2017). Influence of solar declination, photoperiod and irradiation climatic variables at the top of the atmosphere in Brazilian agricultural regions. Journal of Agro-Environmental Sciences, 15(2), 108-115.

https://doi.org/10.5327/z1677-606220171964

Bhering, L. L., Cruz, C. D., Peixoto, L. de A., Rosado, A. M., Laviola, B. G., \& Nascimento, M. (2015). Application of neural networks to predict volume in eucalyptus. Crop Breeding and Applied Biotechnology, 15(3), 125-131.

https://doi.org/10.1590/1984-70332015v15n3a23

Bischoff, T. Z., Simonetti, A. P. M. M., \& Nuernberg, P. H. (2015). Influence of the different temperatures in the development of wheat seeds. Journal of Science and Technology, 12-15.

Camponogara, S., Oliveira, G. A., Georgin, J., \& Rosa, A. L. D. (2016). Assessment of wheat yield when subject to various sources of nitrogen. Electronic Journal in Environmental Management, Education and Technology, 20(1), 524-532.

Campos, B. P. F., Silva, G. F. da, Binoti, D. H. B., Mendonça, A. R. de, \& Leite, H. G. (2016). Estimation of total tree height in plantations of different species through artificial neural networks. Brazilian Forest Research, 36(88), 375-385.

https://doi.org/10.4336/2016.pfb.36.88.1166

Çelebi, K., Uludamar, E., Tosun, E., Yildizhan, S., Aydin, K., \& Ozcanli, M. (2017). Experimental and artificial neural network approach of noise and vibration characteristic of an unmodified diesel engine fuelled with conventional diesel, and biodiesel blends with natural gas addition. Fuel, 197, 159-173. https://doi.org/10.1016/j.fuel.2017.01.113

Costa, J. S. P., Mantai, R. D., Silva, J. A. G., Scremin, O. B., Arenhardt, E. G., \& Lima, A. R. C. (2018). Single and split nitrogen dose in wheat yield indicators. Brazilian Journal of Agricultural and Environmental Engineering, 22(1), 16-21.

https://doi.org/10.1590/1807-1929/agriambi.v22n1p16-21

Cunha, D. A. (2013). Evaluation of Impacts and Adaptation to Climate Change: Models of analysis of the agricultural sector. Journal of Economy and Agribusiness, 10(2), 241-264.

Demuth, H. B., Beale, M. H., Jess, O. D., Hagan, M. T. (2014). Neural network desing. Martin Hagan.

Dornelles, E. F., Kraisig, A. R., da Silva, J. A. G., Sawicki, S., Roos-Frantz, F., \& Carbonera, R. (2018). Artificial intelligence in seeding density optimization and yield simulation for oat. Brazilian Journal of Agricultural and Environmental Engineering, 22(3), 183-188. https://doi.org/10.1590/1807-1929/agriambi.v22n3p183-188 
Fleck, L., Tavares, M. H. F., Eyng, E., Helmann, A. C., \& Andrade, M. A. M. (2016). Artificial Neural Networks: Basic Principles. Electronic journal of Science Innovation and Technology, 1(13), 47-57. https://periodicos.utfpr.edu.br/recit/article/viewFile/4330/Leandro

Frizon, P., Brammer, S. P., Lima, M. I. P. M., Castro, R. L. de, \& Deuner, C. C. (2017). Genetic stability in synthetic wheat accessions: cytogenetic evaluation as a support in breeding programs. Rural Science, 47(4), 1-7. https://doi.org/10.1590/0103-8478cr 20160314

Gonçalves, R. M., Coelho, L. D. S., Krueger, C. P., \& Heck, B. (2010). Shoreline predictive modeling using artificial neural networks. Geodetic Sciences Bulletin, 16(3), 420-444. https://doi.org/10.1590/S1982-21702010000300004

Huang, Y., Lan, Y., Thomson, S. J., Fang, A., Hoffmann, W. C., \& Lacey, R. E. (2010). Development of soft computing and applications in agricultural and biological engineering. Computers and Electronics in Agriculture, 71(2), 107-127.

https://doi.org/10.1016/j.compag.2010.01.001

Junges, A. H., Bremm, C., \& Fontana, D. C. (2019). Rainfall climatology, variability, and trends in Veranópolis, Rio Grande do Sul, Brazil. Brazilian Journal of Agricultural and Environmental Engineering, 23(3), 160-166.

https://doi.org/10.1590/1807-1929/agriambi.v23n3p160-166

Lucena, J. A., Souza, B. I., Moura, M. de O., \& Lima, J. de O. (2012). Rainfall variability as support for agricultural planning in Caicó/RN. Brazilian Journal of Climatology, 10, 121-135. https://doi.org/10.5380/abclima.v10i1.30591

Meireles, M. R. G., \& Cendón, B. V. (2010). Practical application of the content analysis and citation analysis processes in articles related to artificial neural networks. Information \& Information, 15(2), 77-93. https://doi.org/10.5433/1981-8920.2010v15n2p77

Menezes, P. L. de, Azevedo, C. A. V. de, Eyng, E., Dantas Neto, J., \& Lima, V. L. A. (2015). Artificial neural network model for simulation of water distribution in sprinkle irrigation. Brazilian Journal of Agricultural and Environmental Engineering, 19(9), 817-822. https://doi.org/10.1590/1807-1929/agriambi.v19n9p817-822

Perea, R. G., Poyato, E. C., Montesinos, P., \& Díaz, J. A. R. (2018). Optimisation of water demand forecasting by artificial intelligence with short data sets. Biosystems Engineering, 177, 59-66. https://doi.org/10.1016/j.biosystemseng.2018.03.011

Pohlmann, V., \& Lazzari, M. (2018). Climatic characterization of Cachoeira do Sul (Rio Grande do Sul ) and adjacent municipalities regarding air temperature. UERGS Scientific Electronic Journal, 4(5), 643-650. https://doi.org/10.21674/2448-0479.45.643-650

Prando, A. M., Zucareli, C., Fronza, V., Oliveira, F. Á., \& Oliveira Júnior, A. (2013). Productive characteristics of wheat according to nitrogen sources and levels. Tropical Agriculture Research, 43(1), 34-41. https://doi.org/10.1590/S1983-40632013000100009

Reis, L. P., Souza, A. L., Reis, P. C. M. dos R., Mazzei, L., Binoti, D. H. B., \& Leite, H. G. (2018). Prognosis of the diameter distribution in the Amazon by using artificial neural 
networks and cellular automata. Forest, 48(1), 93-102. https://doi.org/10.5380/rf.v48

Rosenblatt, F. (1958). The perceptron: A probabilistic model for information storage and organization in the brain. Psychological Review, 65, 386-408.

https://doi.org/10.1037/h0042519

Sala, V. M. R., Freitas, S. dos S., Donzeli, V. P., Freitas, J. G., Gallo, P. B., \& Silveira, A. P. D. (2005). Occurrence and effect of diazotrophic bacteria in wheat genotypes. Brazilian Journal of Soil Science, 29(1), 345-352. https://doi.org/10.1590/S0100-06832005000300004

Santi, A., Vicari, M. B., Pandolfo, C., Dalmago, G. A., Massignam, A. M., \& Pasinato, A. (2017). Impact of future climate scenarios on the agroclimatic zoning of wheat in the southern region of Brazil. Agrometeoros, 25(2), 303-311.

https://doi.org/10.31062/agrom.v25i2.26167

Santos, F. S., \& Medeiros, S. R. A. (2016). Technologycal prospection on wheat bran use in human consumption. Management, Innovation and Technologies Journal, 6(1), 2861-2873. https://doi.org/10.7198/S2237-0722201600010010

Silva, A. A. V. da, Silva, I. A. F., Teixeira Filho, M. C. M., Buzetti, S., \& Teixeira, M. C. M. (2014). Estimate of wheat grain yield as function of nitrogen fertilization using neuro fuzzy modeling. Brazilian Journal of Agricultural and Environmental Engineering, 18(2), 180-187. https://doi.org/10.1590/s1415-43662014000200008

Silva, I. N., Spatti, H. D., \& Flauzino, R. A. (2010). Artificial Neural Networks: for engineering and applied sciences. São Paulo: Artliber, 399p.

Silva, J. A. G. da, Arenhardt, E. G., Krüger, C. A. M. B., Lucchese, O. A., Metz, M., \& Marolli, A. (2015). The expression of the components of wheat yield by technological class and nitrogen use. Brazilian Journal of Agricultural and Environmental Engineering, 19(1), 27-33. https://doi.org/10.1590/1807-1929/agriambi.v19n1p27-33

Silva, J. P. M., Cabacinha, C. D., Assis, A. L., Monteiro, T. C., Araújo Júnior, C. A., \& Maia, R. D. (2018). Artificial neural network to estimate the basic density of cerrado wood. Brazilian Forest Research, 38, 1-10. https://doi.org/10.4336/2018.pfb.38e201801656

Soares, F. C., Robaina, A. D., Peiter, M. X., \& Russi, J. L. (2015). Corn crop production prediction using artificial neural network. Rural Science, 45(11), 1987-1993.

https://doi.org/10.1590/0103-8478cr20141524

Souza, P. J. O. P., Ramos, T. F., Fiel, L. D. C. S., Farias, V. D. S., Sousa, D. D. P., \& Nunes, H. G. G. C. (2019). Yield and water use efficiency of cowpea under water deficit. Brazilian Journal of Agricultural and Environmental Engineering, 23(2), 119-125.

https://doi.org/10.1590/1807-1929/agriambi.v23n2p119-125

Tedesco, M. J., Gianello, C., Bissani, C. A., Bohnen, H., \& Volkweiss, S. J. (1995). Analysis of soils, plants and other materials. ( $2^{\mathrm{a}}$ ed.) Porto Alegre: Federal University of Rio Grande do Sul, 174p. 


\section{Macrothink}

Teixeira Filho, M. C. M., Buzetti, S., Andreotti, M., Arf, O., \& Benett, C. G. S. (2010). Doses, sources and time of nitrogen application on irrigated wheat under no-tillage. Brazilian Agricultural Research, 45(8), 797-804. https://doi.org/10.1590/s0100-06832008000700015

Teodoro, P. E., Barroso, L. M. A., Nascimento, M., Torres, F. E., Sagrilo, E., dos Santos, A., \& Ribeiro, L. P. (2015). Artificial neural networks to identify semi-prostrate cowpea genotypes with high phenotypic adaptability and stability. Brazilian Agricultural Research, 50(11), 1054-1060. https://doi.org/10.1590/S0100-204X2015001100008

Vendruscolo, D. G. S., Drescher, R., Souza, H. S., Moura, J. P. V. M., Mamoré, F. M. D., \& Siqueira, T. A. da S. (2015). Estimation of eucalyptus height by nonlinear regression and artificial neural networks. Brazilian Journal of Biometrics, 33(4), 556-569.

Viola, R., Benin, G., Cassol, C. L., Pinnow, C., Flores, M. F., \& Bornhofen, E. (2013). Green manure and nitrogen fertilization in the spring wheat under no-tillage. Bragantia, 72(1), 90-100. https://doi.org/10.1590/S0006-87052013005000013

Wasserman, P. D. (1989). Neural computing: theory and pratice. New York: Van Nostrand Reinhold.

\section{Copyright Disclaimer}

Copyright for this article is retained by the author(s), with first publication rights granted to the journal.

This is an open-access article distributed under the terms and conditions of the Creative Commons Attribution license (http://creativecommons.org/licenses/by/4.0/). 